\title{
COMBINATION OF POETIC IMAGERY AND METAPHORICAL THINKING IN POETRY
}

\author{
Supervisor: Sh.Karomova
}

Associate Professor Department Of Literary Studies Karshi State University, Uzbekistan

Dilnavoz Berdieva

Master Student Department Of Literary Studies Karshi State University, Uzbekistan

\section{ABSTRACT}

This article attempts to analyze the figuratively expressed metaphors in the poets' poems. In the process of analysis, we see that the creators used metaphors correctly.

KEYWORDS: - Metaphor, poetic image, image, poetry, lyrical hero, experience, emotion, art.

\section{InTRODUCTION}

Literature is light, literature for the sky of the senses. This is a mysterious Mirror that reveals joys, desires, human happiness and misfortune, dreams and aspirations without lies.

When you look at it, you see flowers, from which sometimes the eyes light up and the heart scatters, and sometimes there are herbs that cause centuries-old pain, and ointments for these pains. This space is Poetry. "This world is the world of art. Its essence is similar to the content of a rainbow, that is, you can see, enjoy, gain strength and, finally, feel, but it is impossible to touch it, to feel through and through. body, because this world is spiritual, not physical.
It also has its own look, but it's far from the picture we're used to. In fact, the images in it are verses"[1. 57]. As you feel and discover this vision, your mind and consciousness are purified and you begin to flow like a leaf in the stream of emotions.

\section{THE MAIN FINDINGS AND RESULTS}

This, of course, depends on the poet's skill, the poet's taste, the beauty of his artistic world, the transparency and depth of his thinking. This contemplation creates an image through words. "Image poetry is the most important element that is not threatened by either time or poetic changes. ... In fiction, all aspects of life can be reflected in vivid images. This is because the very word "property" is the instrument of literature [2.119]. As the poem is created, in addition to a divine power called 
CURRENT RESEARCH JOURNAL OF PHILOLOGICAL SCIENCES 2(10): 01-

05, October 2021

DOI: https://doi.org/10.37547/philological-crjps-02-10-01

ISSN 2767-3758

(C)2021 Master Journals

Crossref do

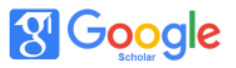

Accepted06 ${ }^{\text {th }}$ October, 2021 \& Published $11^{\text {th }}$ October, 2021

inspiration to make it "more glorious", it is also saturated with the poetic means of imagery that give rise to its poetry, with which it is born. Poetic image. In this case, the idea that the artist is trying to convey is to wear an aesthetic dress, to shine. The ideal of the poet is embodied in front of your eyes. The artistic mood in the poem, the creative spirit begins to flow seamlessly into the heart of the reader.

Bog'larning yuragi gullagan,

Bulutlar baxtiyor qush misol-

Uchadi,

Qanoti ichidan

Zaminga rizq-u ruz qoqadi shamol[3. 29].

The heart of the gardens blossomed,

Clouds are an example of a happy bird-

Flies,

From inside the wing

The wind blows food on the ground

The aforementioned verses of the poetess Kh. Akhmedova describe spring. But the poet does not use the phrase "spring" in this poem. The reader who reads the poem will feel the freshness of spring on its own. As you know, almonds bloom first in spring. The poet describes the blossoming of almonds with the metaphor of "the heart of the garden is in bloom," which in your imagination paints a picture of the gardens in which the squirrel enters the flower. The parable of the clouds symbolizes the movement of the wings of the clouds in the spring sky, and the risk of these wings falling to the ground, that is, rain.

The use of artistic imagery in poetry brings the poem to life, seals the instant reality in your heart, enhances the flavor of the poem.

The means of artistic image and expression arise as a result of deviations from the general norm (ie the use of elements of language in an unusual form, meaning, order, attitude, etc.) with a specific artistic and aesthetic purpose in the use of language [4].

Metaphor is then one of the means of artistic representation. "Metaphor (Greek metaphortransfer) is a type of migration based on the similarity between things, one of the most common types of meaning migration. A metaphor is, in fact, a hidden analogy in which the imitated thing means something similar (that is, the word that expresses it) without mentioning its meaning. In this case, the exact similarity of the simulated object events is not required, but one of two event object-specific symbols is used as a basis.

"Ko'zlaringiz juda chiroyli..."-

Mayusgina shivirlab aytding

Boshim uzra aylandi osmon,

Oy nurida turnalar qaytdi...[5. 35]

"Your eyes are so beautiful..." -

You whispered sadly.

The sky turned over my head,

The cranes are back in the moonlight...

In the cited verses of Zebo-Mirzo, the happiness of the lyrical heroine is expressed in harmony with the image of nature. After hearing the warm words from the lover - "Your eyes are so beautiful" - the situation is expressed by the metaphor "the sky turned over my head." As you know, the phrase "I'm dizzy" is widely used in the speech of our people. The semantic structure of this phrase has two phraseological meanings: 1. meaning "to be in vain", ie to be sick; 2 . the meaning of "stunned". The poet does not say that he is happy and joyful in the praise of his lover, but uses the phrase "dizzy" ("stunned") as "the sky turned over my head", which now expresses his happiness, as well as the level of her joy. It was as if the lover's head was dizzy from the lover's compliment, and even the sky was dizzy when she saw this joy.

One of the active representatives of the modern literary process, Z. Mirzo, is entering the hearts of 
CURRENT RESEARCH JOURNAL OF PHILOLOGICAL SCIENCES 2(10): 01-

05, October 2021

DOI: https://doi.org/10.37547/philological-crjps-02-10-01

ISSN 2767-3758

(C)2021 Master Journals

Crossref do

\section{gil Google}

Accepted06 ${ }^{\text {th }}$ October, 2021 \& Published $11^{\text {th }}$ October, 2021

poets with her "symbolic poetry". Poet love song, hijran nightingale, a pure heart, an innocent look, a fiery pain, a rebellion (separation, emigration, infidelity,) in the iron-like flame of love in his poems disturb the imagination of the reader who reads his poems begin to belong to the poet. As you read the poet's work, "The sorrow that fell the tree of existence" sometimes "likes the spark of love" and sometimes "a thousand rebellions and cries in silence." Sometimes you follow the "light that travels from afar" and fall in love "as if you loved God with one heart."

People's poet of Uzbekistan H. Davron writes: "It is as if the poet has been writing one poem all his life a poem entitled" Love ". Each poem seems to be a continuation of the previous one, fills it, gives it the power to shine even more." [5. 37]

The poet uses poetic means of imagery. In particular, the metaphors are highly skilled in expressing the lyrical hero's experiences in the poem, the image of nature, mother, brothers and love for the Motherland:

Yomg'ir yog'ar,

Nurlar yomg'iri,

Kulib yig'lab ochiladi kun.

Yuragingni qiynar ishq siri,

Derazaga qaraysan mahzun.

It's raining,

Rain of rays,

The day that opens with laughter and tears

The secret of love that breaks your heart,

You look out the window sadly. (Zebo Mirzo. "Love")

In the poem, which begins above, "It rains," the poet describes the reality of the moment in the mind of the lyrical protagonist through the image of rain. The poem is based on metaphor from beginning to end. It reveals the creative experiences of the poet through such metaphors as "rain of rays", "a day that opens with laughter and tears", "the secret of love that breaks your heart". A torrential downpour. Light is light, comfort, serenity, pleasure. Light is hope, light is purity. So, from the first verses, the breath of hope begins to blow. The next line contains a hidden metaphor: "The day that opens with laughter and tears." This implies the movement of rainy clouds in front of the sun, that is, when you look at the spring sky, the "abri naysons" cover the face of the sun, rest, and dance as if in the sky.

In accordance with the mood of the day, the creative mood opens: "the suffering of the heart from the secret of love". The secret is abstraction.

Man strives to unravel this abstraction, and this aspiration requires walking the path of hardship, suffering. It is this torment that afflicts the heart.

Cho'miladi daraxtlar bargi,

Mayning mayin yomg'irlarida.

Oqib ketar dillarning zangi,

Shaffof ko'zyoshlarning bag'rida.

Leaves of bathed trees,

In the light rains of May

The rust of flowing hearts,

In the bosom of transparent eyes (Zebo Mirzo. "Love")

The poet describes the condition of trees in the rain with the verb "to bathe". Bathing - cleansing from hair tips to nails. This means not only the leaves of the tree, but also the purification of all nature with the help of synecdoches. Or the metaphor of "soft rains" as the influence of rain on creative artistic thinking. "Soft!" She is charming, caressing, because her influence on the poet's spirit is gentle.

The third and fourth lines are also a product of metaphorical thinking, especially the metaphor of 
CURRENT RESEARCH JOURNAL OF PHILOLOGICAL SCIENCES 2(10): 01-

05, October 2021

DOI: https://doi.org/10.37547/philological-crjps-02-10-01

ISSN 2767-3758

(C2021 Master Journals

Crossref do

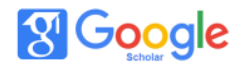

Accepted06 ${ }^{\text {th }}$ October, 2021 \& Published $11^{\text {th }}$ October, 2021

the "Rust of the heart." Rust rusts the iron. It does not appear suddenly, it occurs over the years. The "rust" in the poem is pain. When rust erodes iron, pain erodes the human body, first and foremost the soul.

The author avoids the repetition of rain in the following verses and now uses the metaphor of "in the bosom of transparent eyes", which further enhances the impact of the poem. The rust of hearts flows in the bosom of transparent tears.

In these verses, the image of nature and the creative psyche are combined. When the rain cleanses the whole being, prayer cleanses the mind, the heart. Tears do not come spontaneously. It is either thankfulness to the Truth, or a drop of repentance. Both form "vahdat ul-vujud". In the process, sins are shed and suffering seems to be relieved. There is a special peace in the human soul. In another poem, the poet writes:

Qo'llarimda bir lahza turmay,

Suvga tushib ketgan gavharim

Och to'lqinlar - g'animimgami,

G'amimgami,

Sizni asradim.

Without holding my hand for a moment,

My pearl in the water

Hungry waves - my enemy,

To my grief,

I saved you. (Zebo Mirzo. "Love”)

The "pearl in the water" in the poem is a metaphor for analogy. A gem is a precious stone. The person who has it protects it like the apple of an eye. She is priceless. So, for a lyrical hero, a friend is so precious, like a pupil. And the fact that the diamond fell into the water is a sign that it is lost. Rather than a lost gem combination, the metaphor of "my drowning pearl" expands the range of meaning of the poem, painting its image and providing its imagery. Encourages the reader to think. It also brings a sense of hijra to the reader's mind. it appears then that the metaphor expands the field of image, increasing the artistic value of the poem.

Hunger waves - the metaphor of "hunger" in the form of grief, grief of my enemy, reveal the quality of my enemy, grief. The "hungry waves" are ready to swallow every drop that falls. Grief is sorrow, grief is unhappiness. So, the friend does not drink his happiness, he is lost in his unhappiness

Aristotle writes, "Poetry is the destiny of the gifted or the insane." [1. 59]

Talented people are spiritually very impressionable, and their insanity is prone to madness. Spiritual relations in the poems of the poet, love, its charm, madness; hijran, the creative soul that is burning and purifying in its fire, freezes to its artistic pain and creates changes in the heart of the reader. Ibrahim Haqqul writes: "Poetry is first and foremost a soul. The soul always strives for freedom and beauty" [1.58].

\section{Conclusion}

Z.Mirzo's poems, which also sang hijran, in fact, a desire to move away from hajj, to take himself out of the gardens of hazing, to happiness and joy, which stretches out his hands to him from afar. In the verses encountered in the works of both poets, metaphors not only sought to enhance the charm of the poem, but could also give aesthetic pleasure in conveying beautiful findings to the poet.

\section{REFERENCES}

1. Hamdam.U "The evolution of artistic thinking". Tashkent : "New Uzbek literature" 2002, -pp. 57-59

2. I.Sulton. Literary theory. 2 volumes. 1 vol. Tashkent: 1978. -p. 119 
CURRENT RESEARCH JOURNAL OF PHILOLOGICAL SCIENCES 2(10): 01-

05, October 2021

DOI: https://doi.org/10.37547/philological-crjps-02-10-01

ISSN 2767-3758

(C)2021 Master Journals

7 Crossref dol 81 Google

Accepted06 th October, 2021 \& Published 11 $1^{\text {th }}$ October, 2021

3. Akhmedova Kh. "Green" Tashkent :

"Uzbekistan" publishing house 2016, -p. 29

4. Quronov.D. "Dictionary of literary terms".

Tashkent : "Akademnashr" 2011

5. Zebo Mirzo. "Love” Tashkent: Akademnashr

"2011, -pp. 35-37 